Colton Valentine

Paris IV Sorbonne

École Normale Supérieur

École des Hautes Etudes

en Sciences Sociales
821.09

821.112.2.09 Auerbah E.

821.133.1.09 Poulet G.

https://doi.org/10.18485/climb.2017.5.1.ch7

\title{
CRITICAL DISTANCE IN THE WORKS OF ERICH AUERBACH AND GEORGES POULET
}

\section{Summary}

Much ink has been spilled in recent years over the rapport between the scientific discourse and the various tides of literary theory as they were codified and consecrated in the second half of the twentieth century. According to the common narrative, the appropriation of scientific methodologies in the structuralist paradigm is followed by its direct negation in deconstruction and cultural studies but returned to with unabashed synthesis today in currents as diverse as digital humanities and eco-criticisms. My work interrogates the moment just before this well-mapped chronology, taking as its starting point two theorists, German philologist Erich Auerbach and Swiss critic Georges Poulet, who wrote from decentered positions of (semi)-exile during World War Two, Istanbul and Edinburgh.

The second half of the century would turn its back on these approaches as naively humanistic and non-scientifically rigorous. In retrospect, their celebrated tomes, Mimesis and Studies in Human Time, published in 1946 and 1949 respectively seem like the final gestures of generations of romantic critics. And yet recent decades have seen a new wave of interest in what Auerbach's philological rigor and canny negotiation of national boundaries can add to the discourses of world literature and world circulation. Though no comparable renaissance has emerged for Poulet, no doubt due his impressionistic style and psychoanalytic residues, the deep homologies that exist between their works and their preoccupations demand a revisiting.

Both thinkers quite prophetically believed they were living in a moment of profound rupture with respect to the role of the critic: a time where the objectification of the text threatened to flatten all interpretations of cultural production. And both, as a result, sought new approaches that could remain faithful to the singularity of the work of art as well as the creative role of the critique. In my work, I argue that their innovative systems depended on a tripartite conception of critical distance: one part between a text and its context, the second between the critic and the text, the final between the critic 
and his own context. In elucidating the inner logic of these systems, I seek to visualize a key turning point in discipline of literary theory, to make sense of these last romantics' relationship before the scientific and structuralist waves would sweep, for a time, their methods away.

Key words: Erich Auerbach, Georges Poulet, Literary Theory, Philology, Geneva School, Structuralism

Even the forms of thought and human activity the furthest from us, the most ancient, should be accessible to the possibilities (Vico says "modificazioni") of our own human spirit, in such a way that we can understand them. -Erich Auerbach, Literatursprache und Publikum ${ }^{1}$

That criticism is the substitution of one consciousness for the other, the installation of the first in the sites where the second reigned and from which the intruder will draw it out.

-Georges Poulet, La Conscience Critique ${ }^{2}$

At the middle of the twentieth century, Erich Auerbach and Georges Poulet each published a groundbreaking work of literary criticism: Mimesis (1946) and the first volume of Études sur le temps humain (1949). Composed in Istanbul and in Edinburgh respectively, these chef-d'oeuvres sprung from an era of historical crisis, but they were composed from two places that regarded the kairos of World War Two with a certain detachment. Their twinned successes would bring Auerbach and Poulet from those peripheral positions to center of the international academic field, with appointments at renowned American Universities: Johns Hopkins for Poulet; Pennsylvania then Yale for Auerbach. Their parallel trajectories in the twentieth century, however, have led to radically divergent legacies in the twenty-first.

Recent decades have seen a rise of interest in Auerbach's work on both sides of the Atlantic. In the Francophone sphere, the first translation of his 1952 essay "Philologie der Weltliteratur" in Où est la littérature mondiale? was followed by the first conference on Auerbach organized at the University Paris 3 Sorbonne Nouvelle. In the Anglophone one, Kad-

1 "Auch die von uns entfernsten, frühesten Formen des menschlichen Dekens und Handelns müßten in den Möglichkeiten (Vico sagt modificazioni) unseres eigenen menschlichen Geistes aufzufinden sein, so daß wir sie verstehen können." (All translations are mine.) "C'est la substitution d'une conscience à l'autre, l'installation de la première dans les lieux où régnait la seconde et d'où l'intrus la déloge." 
er Konuk's 2010 biography East West Mimesis: Auerbach in Turkey was followed three years later by James Porter's edited volume Time, History, and Literature: Selected Essays of Erich Auerbach. Scholars like David Damrosch (What is World Literature?) and Emily Apter (The Translation Zone, Against World Literature) have found in Auerbach a comparativist precursor for contemporary world literature studies. Among his cohort of German philologists, from M. K. Vossler to Leo Spitzer and E.R. Curtius, Auerbach stands out due to the breadth of his corpus, the precision of his writing, and his direct engagement with the category of the nation.

It is not surprising, then, that Poulet's oeuvre has experienced no such renaissance. The so-called critic of identification effaces the nation instead of fore-fronting it, his impressionistic writing often positing author psychology and eliding historical context. Yet Poulet and Auerbach were concerned with a fundamentally similar question: how to negotiate the rising stakes of scientific objectivity in literary studies. Both were rooted in the 19th century romantic tradition, which saw literature as a product of authorial genius and a privileged point of access to the spirit of an era. But both were writing just before the structuralists and New Critics reprised Russian formalism to pronounce the death of the author and bestow on the isolated text a formalist, epistemic rigor.

This liminal position is evident in the epigraphs of this essay, in which Auerbach and Poulet comment retrospectively on their own methodologies. In both cases, there is a simultaneous (proto)structuralist commitment to the singular text and a romantic belief that its singularity occurs at the crossroads of an authorial genius and a creative critic. Neither thinker was naive about the stakes of his claim. Indeed, each diagnosed, rather prophetically that the post-war period was a turning point for the critical field, an era that threatened to flatten cultural production and render obsolete those who sought to interpret it. Their conceits, even much of their textual corpuses, were of a piece, though their different intellectual formations inspired divergent approaches and legacies. A comparative study of Auerbach and Poulet's critical praxes shines light on a watershed moment in literary criticism, when the romantic paradigm was about to readapted to scientifically-oriented disciplinary demands.

To model those praxes, I have developed a tri-partite theoretical framework I call "critical distance": a typology of a critic's method made up of three dimensions or branches. The first dimension concerns the dis- 
tance a critic posits between a text and its context, the autonomy that Poulet believes Marcel Proust's À la recherche has from its geographical and temporal position, how much it reflects the France of World War One. The second examines the distance between the critic and the text, the extent to which Auerbach interlaces $A$ la recherche with his own writing, whether he regards it earnestly or skeptically based on his stylistic practices and analytic ends. The third turns to the distance between the critic and his own context, how much Poulet's theories was determined by his position in Edinburgh, Auerbach's citation style by his place in Istanbul.

When synthesized, these three branches - text and context; critic and text; critic and context-give a multi-faceted and organic portrayal of a literary critic's praxis. In typologizing two such praxes, I have two goals, one concrete, the other theoretical. Firstly, I hope to home in on how these two thinkers' unique types of "critical distance" embody two different responses to the collision of (structuralist) Science and (romantic) Culture in mid-twentieth-century literary criticism. Secondly, by displaying the methodological tools and evidentiary support on which relies a study of each dimension of critical distance relies, I hope to show how the model could be applied not only to their contemporaries but just as well to literary critics today.

\section{Text and Context}

To map the first dimension of critical distance, that between text and context, let's turn to two moments in which Auerbach and Poulet suggest the striking autonomy of René Descartes. In "Passio als Leidenschaft," a 1941 essay on the conceptual evolution of passion in France, Auerbach insists on how Descartes' use of the term radically distinguished him from his immediate context. Whereas the predominant 17 th century usage implied that "passions were the grand human desires, and what lead to originality," Descartes' rationalist enterprise demanded a strict equivalence between passion, sentiment, and sensation (173). ${ }^{3}$ This led him, Auerbach argues, to adopt a denotation far closer to "Aristotelian scholasticism": a claim that implicitly alleges high autonomy, or, in my terms, a significant distance between text and context. Notably, Descartes gains this

3 "Die passions sind im französischen 17. Jahrhundert die großen menschlichen Begierden, und das Eigentümliche daran ist die deutliche Neigung." 
place through language: through the way specific words let him identify with Aristotle rather than his immediate environment.

Quite a different model of textual autonomy emerges for Poulet. In the chapter he penned on Descartes in the first volume of Études sur le temps humain, Poulet categorizes the oeuvre's origin as "physical," the progressive textual grafts of an empirical and biological seed. He writes for instance: "That would be the philosophy to which Descartes would arrive under the direct influence of his oneiric experience. All the elements are found in the dreams of the night of the 10th of November" (46). ${ }^{4}$ Significant autonomy emerges once more, for the text is conceived of in a solipsistic dream state, rather than being pre-determined by established cultural norms. Yet whereas Auerbach locates that distance in Descartes' specific linguistic choices, Poulet locates it within his physiology and psyche.

These parallel but divergent explications for writerly autonomy speak to Auerbach and Poulet's distinct scholarly formations. The first was trained in German philology, a discipline whose heritage begins, according to Antoine Compagnon, with Spinoza's Tractatus theologicopoliticus (64-65). By demanding that the Bible be read historically rather than allegorically, Spinoza redefined the task of the biblical exegete: the rigorous reconstruction of the specific sense of words, as points of access to historical concepts. As a philologist of romance literatures, Auerbach applied such techniques to secular texts: the author's language is thus deemed a priori distinct from common usage, enthroned as a privileged point of access to his era's Geist.

Poulet's intellectual formation is far more heterogeneous, the socalled "Geneva School" with which he is grouped having incorporated ideas from the philosophy of Henri Bergson to the psychoanalysis of Sigmund Freud. In Literary Theory: An Introduction, Terry Eagleton argues that the most important heritage was the phenomenology of Edmund Husserl. Husserl sought to reconcile positivism and subjectivism, empiri-

$4 \quad$ "Telle serait la philosophie à laquelle Descartes serait arrivé sous l'influence directe de son expérience onirique. Tous les éléments s'en trouvent dans les songes de la nuit du 10 novembre."

5 A term only applied retroactively, in a 1966 article by J. Hillis Miller, to Poulet's collaborations with Marcel Raymond, Albert Béguin, Jean Rousset, and Jean Starbinski. As Oliver Pot shows in Theoretical Schools and Circles in the Twentieth Century Humanities, the group was indeed united by certain theoretical conceits, such as a belief that form and signification could be synthesized, but they never worked together in a codified school (204). 
cal and psychological approaches to philosophy; when adapted to literary studies the method lauds the imminent experience of reading. The critic is tasked not with accessing the Geist of a text's era, but rather with reconstructing its conceptual Lebenswelt. ${ }^{6}$

Though they seek different ends in reading Descartes, his Geist versus his Lebenswelt, both Auerbach and Poulet's methods give great autonomy to his text relative to its context. At other times, however, both adopt more deductive approaches, fixing the text at the deterministic crossroads of a spatial and a temporal axis.

Auerbach's fidelity to spatial determinism emerges most prominently in his Introduction to romance philology. Its authority emerges firstly in the text's structure, which delimits each era and paradigm according to the national traditions, such that one reads successively about the French Renaissance, the Italian Renaissance, and at last the Spanish Renaissance. ${ }^{7}$ It is redoubled in the content when Auerbach repeatedly insists that national heritages are the primary determinants of a literature's style and quality. Middle Age Spanish literature has a "particular atmosphere, prouder, less soft, and nonetheless closer to reality [...] an atmosphere due, one can only presume, to a particularity of the country, to the fights against the Arabs and to the race that formed under these conditions" (121). ${ }^{8}$ French literature, on the other hand, in deemed preeminent long before the establishment of the nation state- "The oldest literary documents that we possess in a romance language are French" up through the modern era-"Thus results a supremacy of civilization, of language, and of literature, that was all but uncontested until the end of the 18 th century" $(99,172) .^{9}$

6 In Compagnon's words its "profound structures of a vision of the world" that are irreducible to biography, psychology, and historical context (74).

7 These categories certainly do not need to be national ones; an empire, a city, a Parisian arrondissement can equally play the role of spatial determiner. In his 1952 "Philologie der Weltliteratur," in fact, Auerbach would go on to point out that the nation had been replaced as the most essential spatial category, though the works he penned earlier hewed quite closely to national demarcation.

8 "Une atmosphère toute particulière, plus fière, moins douce, et néanmoins plus proche de la réalité [...] atmosphère due, à ce qu'on peut présumer, au sort particulier du pays, aux luttes contre les Arabes et à la race qui s'est formée dans ces conditions."

$9 \quad$ "Les documents littéraires les plus anciens que nous possédions dans une langue romane sont français [...] II en est résulté pour elle une suprématie de civilisation, de langue et de littérature qui a été presque incontestée jusqu’à la fin du xviiie siècle." 
Such a model might seem like a given for a mid-century critic watching a clash of nations play out in World War II. But Poulet's oeuvre shows an almost complete indifference to the country in which his authors were born or lived. Take his chapter on "The Renaissance" in Les Métamorphoses du cercle: Instead of first differentiating the era into his national subsets and then applying those sub-categories to the text like Auerbach, Poulet immediately treats case studies as unique exemplars.

A more explicit justification for this approach comes in the chapter "Romanticism" in which he contends that the aesthetic and conceptual shifts played out identically across national borders: "Almost simultaneously, in France, in Germany, in England, the romantics discovered or rediscovered the essentially religious character of human centrality" (138). ${ }^{10}$ The reference to these nations is all but ironic, serving only to efface their dominance, for any etiological authority vanishes the moment Poulet employs the word "simultaneously."

Though Auerbach and Poulet's methods negotiate the spatial axis differently, they have a shared respect for the temporal one. Almost identical chronologies are recounted, for instance, in the conclusion to Mimesis and introduction to Studies on Human Time. "For the Christian of the Middle Ages, the sense of his existence did not precede that of his continuance" Poulet writes to begin his work, before arguing that one model of time develops synchronically across the European continent (1). ${ }^{11}$ For both critics, that model culminates in the reality-disintegrating, plurivalent perspective of twentieth-century modernists like Marcel Proust.

What emerges is a seeming incongruity in text-context distance: a mix of deductive analyses, which render the text a mere factor of its context, and inductive ones, which emancipate individual texts like those of Descartes. Indeed, there is a constant oscillation in these writers' works between restricted and increased autonomy, lower and higher text-context distance. Those movements testify more to inconstancy than inconsistency, speaking to Auerbach and Poulet's liminal roles between romantic and structuralist criticisms. In different ways, both navigated between

10 “D’ailleurs, presque simultanément, en France, en Allemagne, en Angleterre, les romantiques découvraient ou retrouvaient le caractère essentiellement religieux de la centralité humaine."

11 "Pour le chrétien du moyen âge, le sentiment de son existence actuelle ne précédait pas celui de sa propre durée." 
an old belief in an author's individual genius and a new disenchanted commitment to scientific determinism.

\section{Text and Critic}

A similar navigation emerges in the second dimension of their critical distance: that which pertains not the theoretical presumptions of the literary critic, but to how those predilections manifest in his actual writing. Here, we'll examine the penultimate chapters of Mimesis and Studies on Human Time, both of which treat French 19th century realism, particularly the case of Gustave Flaubert. To do so we'll call on Leo Spitzer "Patterns of Thought in the Style of Albert Thibaudet," in which Spitzer sets a standard for "the possibility of analyzing the style of a literary critic," a method that might, for instance, examine how a critic incorporates textual citations, how he makes use of genre divisions, or even whether he employs the pronoun "I" or "we." In the writings of both Auerbach and Poulet, another dialectic arises: a romantic approach in the stylistic interweaving of Flaubert's citations; a scientific separation when those citations become fodder for extra-textual conclusions.

Poulet launches his chapter at the romantic pole of the dialectic. Taking his epigraph from Flaubert's personal correspondence, Poulet rapidly switches to cite his travel writings, Voyages in the Pyrenees and in Corsica, asserting that these moments of reflection "constitute in the life of Flaubert a series of shining peaks around which all of his work, thought, and existence is arranged" (308). ${ }^{12}$ Here, there is a deifying equivalence of an author's life and his literature, one affirmed by the next set of quotes: three more from Flaubert's correspondence but one from the poem in prose Temptation. Poulet reveals a complete disregard for questions of genre, a symptom of the lack of distance between his own position as a critic and that of the text. This model is reinforced stylistically by the way Poulet hardly demarcates the Flaubert citations, interlacing them not only with each other but also with his own writing. What results is a radical assimilation of the critic and the text.

Yet each cited passage from Flaubert, whether it be epistolary or romanesque, also enters Poulet's chapter because it pertains to a central

"Constituent dans la vie de Flaubert une série de cimes rayonnantes autour desquelles œuvres, pensée, existence, tout se dispose." 
phenomenological conundrum: the mediation between internal and external worlds. "The point of departure for Flaubert is not Flaubert himself," writes Poulet, "but the connection between the perceiving self and the self-perceived" (309). ${ }^{13}$ Establishing a strict thematic conclusion serves to distance the critic from the text being treated because it repositions Flaubert as an object subsumed under Poulet's own conceptual category. Poulet thus interprets Flaubert representation of memory as neither an aesthetic innovation nor as an improved mimesis, but rather as a resolution of a fundamental philosophical issue. Flaubertian realism, for Poulet, should be analyzed not as a stage in literary or social history but rather as an engagement with an internal concern of its Lebenswelt.

In this chapter, Poulet thus oscillates between thematic conclusions that distance the text from the critic and a stylistic treatment of the citations that bring it close. A similar dialectic appears in Auerbach's own chapter on French $19^{\text {th }}$ century realism, in which he treats three cases: Stendhal, Honore de Balzac, and Flaubert. As with Poulet, there is no preamble to position historical context or a thematic end, just a straight plunge into the text. A quick summary, "Julian Sorel, the hero of the novel of Stendhal The Red and the Black (1930), a young ambitious and passionate man" prefaces an extensive block quotation from the novel (400). ${ }^{14}$ And Auerbach repeats the same gesture with Le Père Goriot and Madame Bovary, introducing each only briefly before letting the author's words overwhelm the critic's page. Once again, we have a stylistic practice that strikingly removes distance between the critic and his object of study, romantically enthroning the writer as a sacred figure.

Distance emerges for Auerbach, as for Poulet, retroactively, when the words of the sacred figure are later subsumed under pre-existing categories. After citing and working stylistically through The Red and the Black, Auerbach adds: "What interests us in this scene is the following: it would be all but incomprehensible without the exact, detailed knowledge of the political situation, the social structure, and the economic conditions of a quite certain historical moment" (401). ${ }^{15}$ As a result, Stend-

13 "Le point de départ chez Flaubert ce n'est donc pas Flaubert lui-même, c'est le rapport du moi percevant à l'objet perçu."

14 "Julien Sorel, der Held von Stendhals Roman Le Rouge et le Noir (1830), ein ehrgeiziger und leidenschaftlicher junger Mensch."

15 «Was uns an der Szene interessiert, ist folgendes: sie wäre nahezu unverständlich ohne 
hal's realism is above all a reflection of social context, the direct result of the July Revolution. The same practice is applied to Balzac and then Flaubert, his use of free and indirect style in Madame Bovary ultimately read as a symptom of the rise of the bourgeoisie. Auerbach thus moves dialectically just like Poulet, stylistically approaches the text, but then distancing it by grouping his texts along pre-set categories.

As with their treatment of Descartes, a structural similarity between the praxes of Auerbach and Poulet takes on two subtly different forms. Poulet's analytic objective is a philosophical component of the Lebenswelt, whereas Auerbach's is a socio-historical dimension of a Geist. Both scientifically reduce the text, but Auerbach's manner of doing so is more attractive to contemporary audiences. Similarly, their citational styles may both elide critic-text distance, but they do so in idiosyncratic fashions. Poulet interweaves small excerpts directly into the fabric of his writing, whereas Auerbach isolates one block citation, then proceeds to untangle and examine it from each angle. Auerbach re-cites small phrases in italics, but Poulet italicizes phrases in the original citation, then proceeds to employ them without demarcation. Auerbach's style thus hews more closely to the closereading practices of the New Critics that would dominate in later decades. The two thus straddled sanctifying the singular author and subsuming him under typological categories, giving rise to parallel dialectics between romantic stylistics and scientific analytic ends. It is the nature, not the presence, of each pole that gave rise to such disparate receptions.

\section{Critic and Context}

The final piece to assessing those receptions stems from the distance between each critic and his own context. As a starting point, let's first look at two moments when the writers reflected directly on their perceived autonomy. When Auerbach famously wrote in "Epilegomena zu Mimesis," "Mimesis is a work that is undoubtedly and consciously written by a certain human, in a certain situation, at the beginning of the 1940s,"

die genaueste und detaillierteste Kenntnis der politischen Lage, der gesellschaftlichen Schichtung und der wirtschaftlichen Verhältnisse eines ganz bestimmten geschichtlichen Moments. " 
he pointed to a relative lack of distance (18). ${ }^{16}$ Poulet did the opposite when he cited Jean Starobinski in La Conscience critique: "It is a strange thing to live in the calm and to know at the same time this calm is the exception, that the destiny of the world is playing out beyond" (233). ${ }^{17} \mathrm{We}$ can connect these claims to the analytic ends of each critic, the socio-historical Geist taking precedence for Auerbach, the phenomenological Lebenswelt for Poulet.

But rather than take either interpretation - the determinism of "the certain situation" and the sovereignty of a "playing out beyond" - at face value, it would be more productive to combine them. To see the critic's own text as a product of both a Geist and a Lebenswelt, however, we need to switch methodologies and adapt cultural sociology to the object of literary criticism. For instance, by calling on the concept of the field as defined by Pierre Bourdieu (Les règles de l'art: Genèse et structure du champ littéraire), we can examine a critic's position in a national academic fieldhow similar their methods are to those of the dominant pole. By applying Pascal Casanova's model of an international literary field structured by inequalities between centers and peripheries (La république mondiale des lettres), we can assess whether the semi-peripheral positions of Istanbul and Edinburgh let these critics innovate from, then strike back against more dominant methods.

Auerbach's consistent rejection of German literature, for instance, testifies to significant distance from the dominant pole of his academic system, which was at the time deeply nationalist (Said, xxix; Berthezène, 286). Romance philology, which looked beyond Germany to scrutinize trans-European literature, may now be considered a dominant method, but its proponents were marginalized, then persecuted, in the inter-war period (Varvaro, 72-73). Poulet may not have faced direct discrimination, but his formation in Belgium and failure to acquire a post at a university in Paris or Geneva speaks to his marginal positions (Cudré-Mauroux, 83). The fact that he invented a phenomenological criticism with no single predecessor speaks to an even more remarkable distance from the dominant academic approaches.

16 "Mimesis ist ganz bewußt ein Buch, das ein bestimmter Mensch, in einer bestimmten Lage, zu Anfang der 1940er Jahre geschrieben hat."

17 "C'est une étrange chose que de vivre dans le calme et de savoir en même temps que ce calme est l'exception, et que la destinée du monde se joue ailleurs." 
Alternatively, we could change the scale of "context" and point out that neither Mimesis nor Études sur le temps humain were written in the national fields of those dominant poles, but rather in Istanbul and Edinburg. As Pascale Casanova has shown with cases like James Joyce and Franz Kafka, a semi-peripheral position often stimulates innovation. An Irish or German-speaking Czech writer composes in a dominant language and has partial access to the center's capitol. But their marginality permits aesthetic independence and incites an ardent drive to succeed. Auerbach and Poulet's distance from the dominant academic trends may thus be symptomatic of the "certain situation" of exile.

Taking exile as the context-of-import clarifies the ground-breaking nature of both Mimesis and Études sur le temps humain. But it can only partially explain the writers' later diagnostics of the post-war literary field. In his now-beloved "Philologie der Weltliteratur," Auerbach warned that the effacement of national boundaries would blur distinctions between each country's cultural output and level all literatures into a single globalized mass. He spied a parallel relativism in literary works themselves. In the final pages of Mimesis, for instance, Auerbach pinpointed the way modernist writers like Virginia Woolf and Marcel Proust sought to multiply perspectival realities. Though they aimed to coalesce those realities into an objective viewpoint, Auerbach felt the fracturing spoke to a paradigmatic swing to subjectivism: one that could justify any textual interpretation and any fascist doctrine.

Poulet was worried about the precise opposite trend. He saw subjectivization as not only permissible, but indeed essential for a proper act of phenomenological identification: the installation of the critic's consciousness within that text. His anxiety concerned critical methods that sought to falsely objectivize the text, a trend incarnated by Roland Barthes, whose work posited an "impersonal mirror where the object, nothing but the object, revealed itself in its layout, in its composition, in the relations of its parts, in its linguistic order" (267). ${ }^{18}$ Such a practice was deeply troubling for Poulet because it evinced the creative role played by both critic and author to constitute that textual object.

"Miroir impersonnel où l'objet, rien que l'objet, se révèle dans son agencement, dans sa composition, dans les relations de ses parties, dans son ordre linguistique." 
These diagnoses can only be partially explained by the Auerbachmodel of the "certain situation" of exile, for if they were both representative of the post-War Geist they arrived at exact opposite conclusions. If we incorporate the Poulet-model of that Geist "playing out beyond," however, we can see them as oriented by the critics' personal methodological requirements. Each, then, is a reactive attempt to safeguard the internal coherency of a Lebenswelt. Auerbach's anxiety, for instance, is very much a symptom of the way philology relies on national demarcations and historical referents; Poulet's grows out of phenomenological criticism's insistence on the primacy of mental categories.

At their crossroads emerges a more nuanced account of the turn in mid-century literary criticism: fear of subjectivization encourages the import of scientifically rigorous methodologies that, in turn, beget a perceived threat of over-objectification. Auerbach and Poulet prophesized this single turn from different angles, composing threshold oeuvres that serve as parallel testimonies. Like his methods, Auerbach's judgments hew more closely to our contemporary anxieties: a globalized and flattened world, a post-truth paradigm denying singular reality. But the way that Poulet drew parallel conclusions from analogous data invites a more serious re-appraisal of his work. We would do well to look with phenomenological lenses on our newest digital phase of objectivism: the radical reduction of humanistic texts to data points for algorithmic analysis.

In teasing out the three dimensions of critical distance that structure Auerbach and Poulet's praxes, I have sought first and foremost to typologize two responses to a mid-century struggle between science and culture: a fading romantic paradigm running into a rising structuralist one. To do so, I have combined schematic readings with stylistic analyses, then placed those internal exegeses in conversation with the external tools of cultural sociology. Ultimately, I hope not just to have shed comparative light on two mid-century thinkers, but also to have presented a theoretical model for future such inquiries. Understood organically, "critical distance" grasps not just how one thinker navigates the ever-changing relationship of culture and science, but also why parallel enterprises, like Mimesis and Études sur le temps humain, can foster such different receptions that one chef-d'oeuvre still awaits its renaissance. 


\section{Works Cited}

Apter, Emily. Against World Literature: On the Politics of Untranslatability. New York: Verso, 2013.

-. The Translation Zone: A New Comparative Literature. Princeton: Princeton UP, 2006.

Auerbach, Erich. "Epilegomena zu Mimesis." Romanische Forschungen, vol. 65, no. 1/2, 1953, pp. 1-18.

-. Introduction aux études de philologie romane. 1949. Frankfurt: Vittorio and Klostermann, 1965.

—. Mimesis: dargestellte Wirklichkeit in der abendländischen Literatur. Bern: Francke, 1946.

- Literatursprache und Publikum in der lateinischen Spätantike und im Mittelalter. Bern: Francke, 1958.

—. "Passio als Leidenschaft." 1941. Publications of the Modern Language Association of America, vol. 56, pp. 1179-1196. Republished in Gesammelte Aufsätze zur Romanischen Philologie, Bern: Francke, 1967, pp. 161-175.

- . "Philologie der Weltliteratur." Weltliteratur. Festgabe für Frtiz Strich, Bern: Francke, 1952, pp. 39-50.

Berthezène, Diane. "Bibliographie, Introduction." Erich Auerbach la littérature en perspective, edited by Paolo Tortonese, Paris: Presses Sorbonne Nouvelle, 2009, pp. 285-294.

Bourdieu, Pierre. Les règles de l'art: Genèse et structure du champ littéraire. Paris: Éditions du Seuil, 1998.

Casanova, Pascale. La République mondiale des Lettres. Paris: Éditions du Seuil, 2008.

Compagnon, Antoine. Le démon de la théorie. Paris: Éditions du Seuil, 1998.

Cudré-Mauroux, Stéphanie. "Amitiés épistolaires de Georges Poulet" in "Dossier français. Postérité de l'École de Genève." Critica littéraire Quarto, Archives littéraires suisses, 2015-2016, pp. 83-95.

Damrosch, David. What is World Literature?. Princeton: Princeton UP, 2003.

Eagleton, Terry. Literary Theory: An Introduction, 1983, Anniversary ed. Malden, MA: Backwell, 2008.

Konuk, Kader. East West Mimesis: Auerbach in Turkey. Stanford: Stanford UP, 2010.

Pot, Oliver. "The Geneva School: Form and Signification in Motion." Translated by Helena

Taylor. Theoretical Schools and Circles in the Twentieth Century Humanities, edited by Marina Grishakova and Silvi Salupere, New York: Routledge, 2015, pp. 188-210.

Poulet, Georges. La Conscience critique. Paris: José Corti, 1971.

—. Études sur le temps humain. 1949. Paris: Libraire Plon, 1950.

- Les Métamorphoses du cercle. Paris: Librairie Plon, 1961.

Saïd, Edward. "Introduction to the fiftieth-anniversary edition." Mimesis: the representation of reality in Western literature, Princeton: Princeton UP, 2003, pp. ix-xxxii.

Spitzer, Leo. "Patterns of Thought in the Style of Albert Thibaudet." Modern Language Quarterly, no.9, 1948, pp. 259-72.

Varvaro Albert. "Mimesis avant Mimesis." Erich Auerbach la littérature en perspective, edited by Paolo Tortonese, Paris: Presses Sorbonne Nouvelle, 2009, pp. 71-88. 


\section{Колтон Валентин}

Париз IV Сорбона

EHC (École Normale Supérieur)

Школа за напредне студије друштвених наука

\section{КРИТИЧКА ДИСТАНЦА У ДЕЛИМА ЕРИХА АУЕРБАХА И ЖОРЖА ПУЛЕА}

\section{Сажетак}

Много тога је написано у последњих неколико година о односу између научног дискурса и различитих плима књижевне теорије, које су кодифициране и прихваћене као општеважеће у другој половини двадесетог века. У складу са општеприхваћеним наративом, присвајање научних методологија у структуралистичкој парадигми прати њено директно негирање у деконструкцији и културним студијама, али им се и данас враћамо кроз одважну синтезу струја које се у великој мери међусобно разликују, попут дигиталне хуманистике и еко-критике. Мој рад испитује тренутак пре ове јасно дефинисане хронологије, узимајући као полазну тачку два теоретичара, немачког филолога Ериха Ауербаха и швајцарског критичара Жорж Пулеа, који су писали са децентрализованих позиција у (полу) егзилу током Другог светског рата, у Истанбулу и Единбургу.

Друга половина века ће окренути леђа овим приступима као наивно хуманистичким и ненаучно ригорозним. У ретроспективи, њихови прослављени томови, Мимезис и студије људског времена, објављени 1946. и 1949. године, данас изгледају као последњи гестови генерација романтичарских критичара. Па ипак, последњих деценија дошло је до новог таласа интересовања за оно што Ауербахова филолошка строгост и лукаво преговарање о националним границама може придодати дискурсу светске књижевности и њене распрострањености на светском нивоу. Иако Пуле не сматра да се ренесанса тих размера уопште одиграла, несумњиво због његовог импресионистичког стила и остатака психоаналитичких утицаја, дубоке хомологије које постоје између њихових дела и њихових предмета интересовања захтевају поновно разматрање.

Оба мислиоца су доста пророчки веровала да живе у доба дубоког раскола по питању улоге критичара: у времену када објектификација текста прети да поруши сва тумачења културне продукције. Управо из овог разлога и један и други су тражили нове приступе који би могли остати верни јединственој природи уметничких дела, као и креативној улози критике. У раду напомињем да су њихови 
иновативни системи зависили од троделне концепције критичке дистанце: први део је онај који постоји између одређеног текста и његовог контекста, други између критичара и текста, а последњи између критичара и његовог контекста. Расветљавајући унутрашњу логику ових система, настојаћу да визуализујем кључну прекретницу у области књижевне теорије, образложим однос између ова два последња романтичара пре него што научне и структуралистичке струје, кроз неко време, укину њихове методе.

Кључне речи: Ерих Ауербах, Жорж Пуле, књижевна теорија, филологија, Женевска школа, структурализам 